\title{
EFFECTS OF FOREST EXPANSION AND LAND ABANDONMENT ON ECOSYSTEM SERVICES OF ALPINE ENVIRONMENTS: CASE STUDY IN LEDRO VALLEY (ITALY) FOR THE PERIOD 1859-2011
}

\author{
FEDRIGOTTI C. \\ ASCHONITIS V. ${ }^{*}$ \\ FANO E.A.
}

Received: 22/09/2015

Accepted: 15/11/2016

Available online: 17/11/2016
Department of Life Sciences and Biotechnology

University of Ferrara

Via L. Borsari 46, 44121, Ferrara, Italy

*to whom all correspondence should be addressed: e-mail: schvls@unife.it

\section{ABSTRACT}

During the last century, the European Alps have faced intense socio-economic changes, which have led to respective land-use changes with immediate impact on ecosystem services (ESs). The aim of the study is to present the land-use changes and their effects on the economical contribution of ESs in the alpine environment of Ledro Valley, in Northern Italy. Data were collected through historical cartography and photographic material from 1859, 1973 and 2011. The analysis of landscape evolution highlighted the forest expansion, and partially the urban expansion, at the expense of grasslands and croplands due to a transition from a rural to a touristic and handcrafting economy. The land-use changes led to an overall reduction of the economical contribution of ESs, while further analysis on individual services identified advantages and disadvantages caused by the re-naturalization process of forest expansion. The results suggested that the profit maximization of ESs under the pressure of such land-use changes can be achieved by a) a respective profit maximization from services related to recreation activities (tourism) which have an immediate economical impact on local economies and b) the maintenance and sustainable management of the typical rural landscape and grasslands in order to preserve some of their economical benefits.

Keywords: Alpine environment, land-use change, ecosystem services, forest expansion, land abandonment.

\section{Introduction}

Ecosystems provide a range of services, many of which are of fundamental importance to human wellbeing, health, livelihoods, and survival. The economical contribution of such services can be evaluated using the reference system of monetary indicators proposed by Costanza et al., $(1997,2014)$ and de Groot et al., (2012), which is considered an extremely useful tool for the development of landscape management plans. The landscape of Alps is considered one of the most important natural territories of Europe and provides a great number of ecosystem services (ESs): protection from natural hazards, $\mathrm{CO}_{2}$ storage and accumulation in soil or biomass, provisioning of raw materials and water, genetic diversity and touristic opportunities (Grêt-Regamey et al., 2008). During the second half of 20th century, socio-economic changes caused a modification in the use of Alpine territories towards a greater exploitation or a complete abandonment (Chauchard et al., 2007; Rutherford et al., 2008; Prévosto et al., 2011; Cocca et al., 2012). 
These alterations are considered the main causes of variations observed in species diversity, ecosystem functionality, landscape configuration, and economical growth of the local communities (Tasser et al., 2005; 2007).

Many administrative units and scientists demonstrated a growing interest in the development of landscape and urban development plans for the alpine territories (Scolozzi et al., 2010; Fontana et al., 2013; Schirpke et al., 2013; Ferrari and Geneletti, 2014) which are considered among the most interesting places for analyzing the evolution of land-use changes and the interdependence of multiple ecosystem services in terms of their synergies and trade-offs (Bennett et al., 2009; Nelson et al., 2009; Power, 2010; Schirpke et al., 2013).

The aim of the study is to present the land-use changes and their effects on the economical contribution of ESs in the alpine environment of Ledro Valley, in Northern Italy, during the period 1859-2011. The study area and the evolution of its landscape during the 152-years period is representative of the Italian alpine environments and can provide significant information about the economical impact of land-use changes through ESs analysis.

\section{Data and methods}

\subsection{Study area and data}

Ledro Valley $\left(45^{\circ} 87^{\prime} 0^{\prime \prime} \mathrm{N}, 10^{\circ} 76^{\prime} 0^{\prime \prime} \mathrm{E}\right)$ is located in the southern area of Alpine chain, in south-western Trentino in Italy (Fig.1). The total coverage of the study area is almost $\sim 200 \mathrm{Km}^{2}$ with altitude ranging between $65 \mathrm{~m}$ (edge of Garda Lake) and $2253 \mathrm{~m}$ (Cima Geometra). The mean annual precipitation is 1300 $\mathrm{mm}$ and the mean annual temperature is around $9-10^{\circ} \mathrm{C}$ (Cigalotti, 1973). The variety of environmental conditions, in association with the particular geological history (AA.VV., 2012), are among the main reasons of the exceptional natural heritage of Ledro district, which includes 22 botanical endemic species and several priority habitats according to 92/43/EEC. Five Natura 2000 sites are located within its boundaries, which combine $4 \mathrm{SCls}$ (Sites of Community Importance) and 3 SPAs (Special Protection Areas). From a socio-economic point of view, until the beginning of the second half of XX century, the study area was characterized by an economy mainly based on traditional activities, linked to agriculture and farming. Nowadays, traditional land-use has largely reduced and Ledro Valley is characterized by an economy mostly based on tourism and handcrafting.

\subsection{Analysis of landscape evolution}

The evolution of Ledro landscape was analyzed using cartographic material from 1859 (Hapsburgic cadaster), 1973 and 2011; 1973 (Digital Orthophoto - Autonomous Province of Trento) and 2011 (Digital Orthophoto - Autonomous Province of Trento), covering a total period of 152 years. Land-use mapping (Fig.1) was performed using two GIS software packages: Quantum GIS Brighton (ver.2.6.1.) and Global Mapper v.11 (Global Mapper Software LLC). Nine basic land-uses were identified: 1. Forest (including both coniferous forest and deciduous forests), 2. Pastures, 3. Permanent meadows, 4. Croplands, 5. Inland waters, 6. Sandy river banks, 7. Inland wetlands, 8. Discontinuous urban fabric, 9. Buildings.

Landscape evolution was analyzed according to five elevation zones: 65-600 m, 600-1000 m, 1000-1600 $\mathrm{m}, 1600-2000 \mathrm{~m}, 2000-2300 \mathrm{~m}$. The statistically significant changes were tested on the base of comparison of proportions with $\chi^{2}$ test for $P$-value $\leq 0.01$, using StatGraphics Centurion XV (StatPoint Inc.). For each elevation zone, the comparison was performed between the total area of each land-use type of the three years 1859, 1973, 2011 with the overall extension of the remaining ecosystem types (for instance, Forest and Non-forest). The null hypothesis was that the extension of the two classes didn't change over the years $1859,1973,2011$. Together with $\chi^{2}$ test, the analysis of means (ANOM) plot with $99 \%$ confidence limits was also used. Based on the ANOM plot, three codes $a, b$ and $c$ were used to denote the location of the proportion values from the three dates: above, inside and below the $99 \%$ confidence limits. This procedure was not used to denote statistical differences between the years (e.g. as in the case of LSD test 
in ANOVA) but to provide some indications about the direction of the most extreme changes, based on the deviation from the grand mean of the ANOM plots.
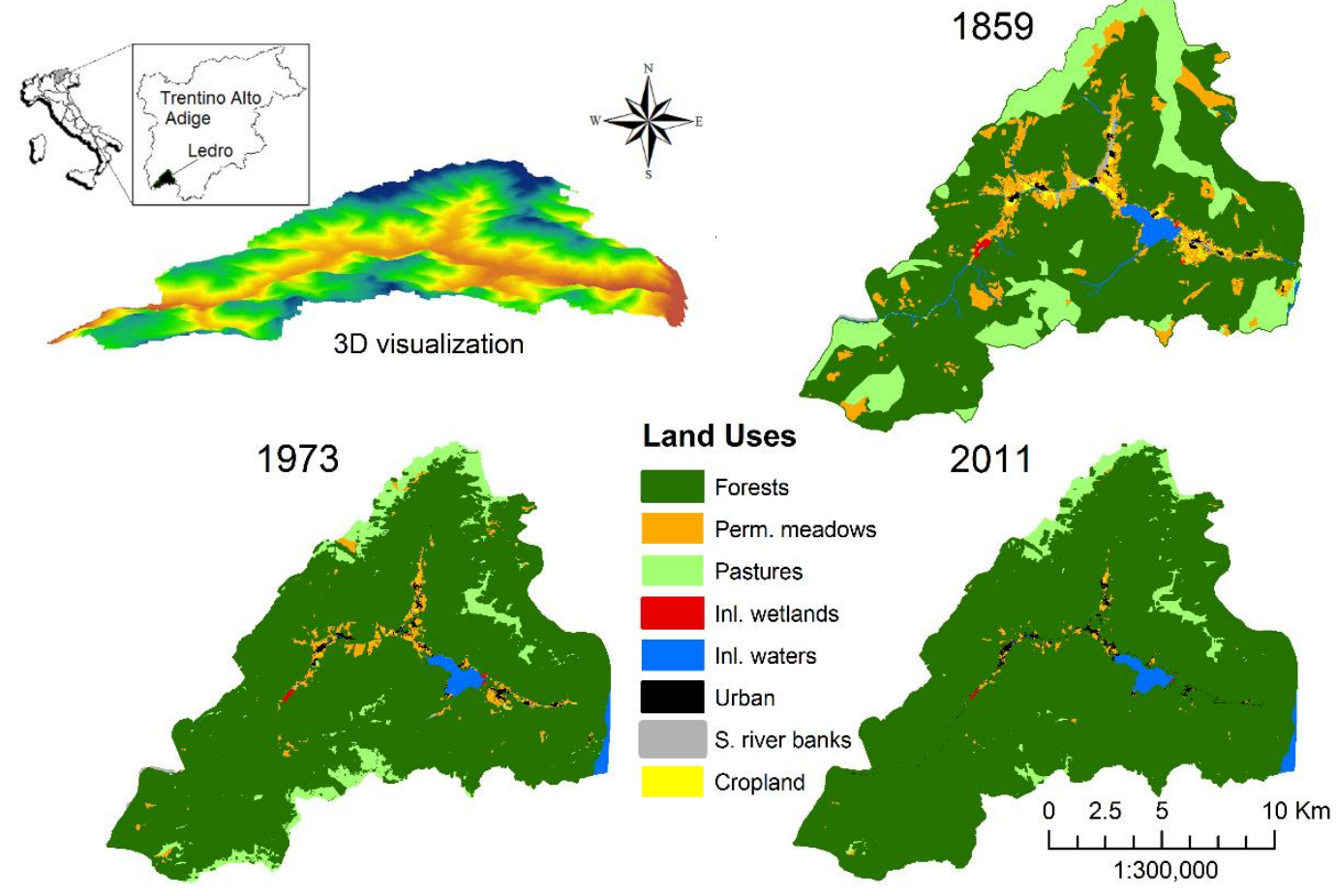

Figure 1. 3D terrain visualization and land-uses of Ledro valley for the years 1859, 1973 and 2011

("Urban" includes both "Discontinuous urban fabric" and "Buildings")

\subsection{Evaluation system of ecosystem services}

The economic value of ESs for each land-use was obtained by Costanza et al., (2014) (provided in USD\$2007) after modifications from de Groot et al., (2012). Evaluations were updated to euro EU€2015 monetary values using the Inflation calculator (http://www.usinflationcalculator.com/) to convert from USD\$2007 to USD\$2015 (inflation factor=1.15) and the monetary convertor (www.fxtop.com) to convert from USD\$2015 to EU€2015 (conversion factor $=0.88$ ). The monetary values of five ecosystem categories were used for the evaluation of ESs: 1. Temperate forests, 2. Grasslands, 3. Croplands, 4. Inland wetlands and 5. Inland waters (Costanza et al., 2014). Their updated monetary values in EU€2015/ha/year are given in Table 1. These ecosystem typologies were used as a proxy for each land-use of Ledro valley. The categories of "Discontinuous urban fabric" and "Buildings" do not provide ESs and for this reason were excluded; the "Pastures" and "Permanent meadows" were considered as "Grasslands" since they provide the same ESs, while the "Sandy river banks" were grouped together with "Inland waters" since their area is covered by water, especially during winter. The overall value of ESs provided by the study area in 1859, 1973 and 2011 was finally estimated by multiplying the area of each land-use with the respective updated values from Table 1.

\section{Results}

\subsection{Land use changes}

The coverage of land-use and the land-use changes based on the five different elevation zones for the respective periods are given in Table 2 and the results of $\chi^{2}$ tests are given in Table 3.

According to Table 2 and 3, significant land-use changes were not observed in the higher elevation zone (2000-2300 m), while the categories of "Inland waters", "Inland wetlands" and "Buildings" showed no 
significant changes in all elevation zones during the 152-years period. For the case of "Inland waters", there was a change in their spatial distribution between the land-use maps of 1859 and 1973, because part of the area covered by streams and part of the small lake Ledro in the center of the study area was lost. This territorial loss of inland waters was counterbalanced by the rise in water level of Garda Lake at the eastern boundaries of the territory, which increased lake's area as it is evident in Fig.1. This rise occurred in 1950 when the lake was closed by an artificial barrier built on the Mincio in SalionzeMonzambano (Piccolroaz et al., 2013).

Table 1. Monetary values for each ecosystem service per biome, according to de Groot et al., (2012) and Costanza et al., (2014) after conversion to EU€2015/ha/yr

\begin{tabular}{|c|c|c|c|c|c|c|}
\hline \multirow{2}{*}{\multicolumn{2}{|c|}{$\begin{array}{l}\text { Ecosystem Services } \\
\text { in EU€2015 }\end{array}$}} & \multicolumn{5}{|c|}{ Ecosystem type } \\
\hline & & Temperate forest & Grasslands & Inl. Wetlands & Inl.waters & Croplands \\
\hline \multirow{5}{*}{ 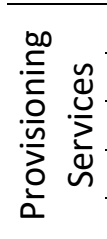 } & Food production & 302.59 & $1,206.30$ & 963.42 & 107.27 & $2,350.88$ \\
\hline & Raw materials & 183.17 & 54.65 & 420.99 & - & 221.63 \\
\hline & Genetic resources & - & $1,228.57$ & 245.92 & - & $1,054.50$ \\
\hline & Water supply & 193.29 & 60.72 & 970.51 & $1,829.70$ & 404.80 \\
\hline & Total Prov. Services & 679.05 & $2,550.24$ & $2,600.84$ & $1,936.97$ & $4,031.81$ \\
\hline \multirow{9}{*}{ 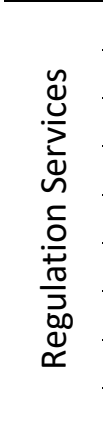 } & Gas regulation & - & 9.11 & - & - & - \\
\hline & Climate regulation & 153.82 & 40.48 & 202.40 & - & 415.93 \\
\hline & Disturbance regulation & - & - & $4,651.15$ & - & - \\
\hline & $\begin{array}{c}\text { Erosion control } \\
\end{array}$ & $5.06+$ & 44.53 & $3,549.08$ & - & 108.28 \\
\hline & Waste treatment & 121.44 & 75.90 & $112,681.14$ & 929.02 & 401.76 \\
\hline & Biological control & 237.82 & 31.37 & 306.64 & - & 33.40 \\
\hline & Water regulation & - & 3.04 & $1,810.47$ & $7,604.17$ & - \\
\hline & Nutrient cycling & 94.12 & - & 583.92 & - & - \\
\hline & Total Regul. Services & 612.26 & 204.42 & $123,784.80$ & $8,533.18$ & 959.38 \\
\hline \multirow{4}{*}{ 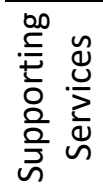 } & Soil formation & 14.17 & 2.02 & - & - & 538.38 \\
\hline & Pollination & - & 35.42 & - & - & 22.26 \\
\hline & Habitat refugia & 872.34 & $1,228.57$ & $12,601.42$ & - & - \\
\hline & Total Support. Services & 886.51 & $1,266.01$ & $12,601.42$ & - & 560.65 \\
\hline \multirow{3}{*}{ 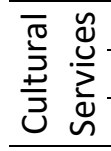 } & Recreation & $1,000.87$ & 26.31 & $2,225.39$ & $2,191.99$ & 82.98 \\
\hline & Other Cultural* & 1.01 & 169.00 & 643.63 & - & - \\
\hline & Total Cult. Services & $1,001.88$ & 195.32 & $2,869.02$ & $2,191.99$ & 82.98 \\
\hline \multicolumn{2}{|c|}{ Total of Ecosystem Services } & $3,179.70$ & $4,215.99$ & $141,856.09$ & $12,662.14$ & $5,634.82$ \\
\hline
\end{tabular}

From the remaining land-uses, the categories of "Forest" and "Discontinuous urban fabric" showed a statistically significant increase of their coverage while the categories "Pastures", "Permanent meadows", "Arable land" and "Sandy river banks" a statistically significant decrease during the 152-years period (Table 3).

The coverage of forests increased from $65.7 \%$ of the total area in 1859 , to $75.2 \%$ in 1973 and to $82.6 \%$ in 2011 (3301 ha gained in 152-years period). For the elevation zones between 65-1600 m, the increase of forest mostly happened before 1973 while for the elevation zone 1600-2000 m mostly happened after 1973. Forest expansion in these elevation zones mainly reduced the summarized coverage of both "Pastures" and "Permanent meadows" from $30.4 \%$ of the total area in 1859, to $22.4 \%$ in 1973 and to $14.6 \%$ in 2011 (3088 ha lost in 152-years period).

In the two lower elevation zones (65-600 and 600-1000 m), which correspond to the valley floor, it was found a large reduction of both "Croplands" and "Sandy river banks" mainly due to the increase of "Discontinuous urban fabric" but also by some expansion of "Pastures" and "Permanent meadows". The 
reduction of "Croplands" mostly happened before 1973 and its coverage in 2011 was only 20.8 ha (0.11\% of the total area) with an overall loss of $94.8 \%$ since 1859 (380 ha lost in 152-years period). The "Sandy river banks" gradually decreased reaching 4.4 ha $(0.02 \%$ of the total area) with an overall loss of $86 \%$ since 1859 ( 27 ha lost in 152-years period). The "Discontinuous urban fabric" mainly increased in the zone of $600-1000 \mathrm{~m}$ from $0.21 \%$ of the total area in 1859, to $0.72 \%$ in 1973 and to $1.19 \%$ in 2011 (191 ha gained in 152-years period).

Table 2. Coverage of land-uses and land-use changes for five different elevation zones of the Ledro valley for the years 1859, 1973 and 2011

\section{LAND-USE 1859 [ha]}

\begin{tabular}{|c|c|c|c|c|c|c|c|c|c|c|c|}
\hline $\begin{array}{l}\text { Altitude } \\
\text { [m a.s.l.] }\end{array}$ & Forest & Pastures & $\begin{array}{l}\text { Permanent } \\
\text { meadow }\end{array}$ & $\begin{array}{l}\text { Crop } \\
\text { land }\end{array}$ & $\begin{array}{l}\text { Inland } \\
\text { waters }\end{array}$ & $\begin{array}{c}\text { S.R. } \\
\text { Banks }\end{array}$ & $\begin{array}{c}\text { Inland } \\
\text { wetlands }\end{array}$ & $\begin{array}{l}\text { Discontinuous } \\
\text { urban fabric }\end{array}$ & S Buildings & $\begin{array}{l}\text { Total } \\
\text { [ha] }\end{array}$ & $\begin{array}{c}\text { Total } \\
\text { [\%] }\end{array}$ \\
\hline $2000-2300$ & 11.98 & 131.1 & - & - & - & - & - & - & - & 143 & $0.74 \%$ \\
\hline $1600-2000$ & 705.3 & 1664.4 & 69.77 & - & - & - & - & - & 0.24 & 2440 & $12.53 \%$ \\
\hline $1000-1600$ & 7545.05 & 1599.43 & 802.18 & 2.01 & 2.19 & - & - & - & 1.79 & 9953 & $51.13 \%$ \\
\hline $600-1000$ & 4109.66 & 207.69 & 1106.39 & 346.79 & 253.722 & 22.18 & 10.99 & 35.03 & 7.33 & 6100 & $31.34 \%$ \\
\hline $65-600$ & 407.17 & 233.04 & 106.85 & 51.99 & 15.82 & 9.08 & - & 6.17 & 0.89 & 831 & $4.27 \%$ \\
\hline Total [ha] & 12779.16 & 3835.66 & 2085.19 & 400.79 & 271.732 & 31.26 & 10.99 & 41.2 & 10.25 & 19466 & $5100 \%$ \\
\hline Total [\%] & $65.65 \%$ & $19.70 \%$ & $10.71 \%$ & $2.06 \%$ & $1.40 \%$ & $0.16 \%$ & $0.06 \%$ & $0.21 \%$ & $0.05 \%$ & $100 \%$ & \\
\hline
\end{tabular}

LAND-USE 1973 [ha]

\begin{tabular}{|c|c|c|c|c|c|c|c|c|c|c|c|}
\hline $\begin{array}{l}\text { Altitude } \\
\text { [m a.s.I.] }\end{array}$ & Forest & Pastures ${ }^{\mathrm{F}}$ & $\begin{array}{c}\text { Permanent } \\
\text { meadow }\end{array}$ & $\begin{array}{l}\text { Crop } \\
\text { land }\end{array}$ & $\begin{array}{l}\text { Inland } \\
\text { waters }\end{array}$ & $\begin{array}{c}\text { S.R. } \\
\text { Banks }\end{array}$ & $\begin{array}{c}\text { Inland } \\
\text { wetlands }\end{array}$ & $\begin{array}{l}\text { Discontinuous } \\
\text { urban fabric }\end{array}$ & Suildings & $\begin{array}{l}\text { Total } \\
\text { [ha] }\end{array}$ & $\begin{array}{c}\text { Total } \\
{[\%]}\end{array}$ \\
\hline $2000-2300$ & 2.57 & 140.5 & - & - & - & - & - & - & - & 143 & $0.74 \%$ \\
\hline $1600-2000$ & 603.15 & 1749.4 & 76.56 & - & - & - & - & - & 0.12 & 2440 & $12.53 \%$ \\
\hline $1000-1600$ & 8696.6 & 881.8 & 378.9 & 0 & 1.9 & - & - & - & 4.6 & 9953 & $51.13 \%$ \\
\hline $600-1000$ & 4670.04 & 22.5 & 970.7 & 34.48 & 242 & 9.37 & 12.08 & 126.6 & 11.8 & 61003 & $31.33 \%$ \\
\hline $65-600$ & 658.73 & 44.3 & 87.31 & 11.48 & 12.37 & 1.63 & - & 14.4 & 1.01 & 831 & $4.27 \%$ \\
\hline Total [ha] & 14631.09 & 2838.55 & 1513.47 & 45.96 & 256.27 & 11 & 12.08 & 141 & 17.53 & 19466 & $100 \%$ \\
\hline Total [\%] & $75.16 \%$ & $14.58 \%$ & $7.77 \%$ & $0.24 \%$ & $1.32 \%$ & $0.06 \%$ & $0.06 \%$ & $0.72 \%$ & $0.09 \%$ & $100 \%$ & \\
\hline $\begin{array}{l}\% \text { Change } \\
\text { from } 1859\end{array}$ & $14.49 \%$ & $-26.00 \%$ & $-27.42 \%$ & & & & $9.92 \%$ & $242.23 \%$ & $71.02 \%$ & & \\
\hline
\end{tabular}

LAND-USE 2011 [ha]

\begin{tabular}{cccccccccccc}
\hline $\begin{array}{c}\text { Altitude } \\
\text { [m a.s.I.] }\end{array}$ & Forest & Pastures & $\begin{array}{c}\text { Permanent } \\
\text { meadow }\end{array}$ & $\begin{array}{c}\text { Crop } \\
\text { land }\end{array}$ & $\begin{array}{c}\text { Inland } \\
\text { waters }\end{array}$ & $\begin{array}{c}\text { S.R. } \\
\text { Banks }\end{array}$ & $\begin{array}{c}\text { Inland Discontinuous } \\
\text { wetlands urban fabric }\end{array}$ & $\begin{array}{c}\text { Tuildings } \\
\text { [ha] }\end{array}$ & $\begin{array}{c}\text { Total } \\
\text { [\%] }\end{array}$ \\
\hline $2000-2300$ & 9.39 & 133.69 & - & - & - & - & - & - & - & 143 & $0.74 \%$ \\
\hline $1600-2000$ & 1312.3 & 1104.79 & 21.56 & - & 0.21 & - & - & - & 0.85 & 2440 & $12.53 \%$ \\
\hline $1000-1600$ & 9244.02 & 480.15 & 219.29 & 0.05 & 4.45 & - & - & - & 4.69 & 9953 & $51.13 \%$ \\
\hline $600-1000$ & 4821.72 & 26.68 & 756.62 & 11.7 & 239.22 & 4.37 & 9.1 & 212.91 & 17.31 & $610031.34 \%$ \\
\hline $65-600$ & 692.72 & 32.38 & 58.03 & 9.03 & 18.4 & 0 & - & 18.79 & 1.66 & 831 & $4.27 \%$ \\
\hline Total [ha] & 16080.15 & 1777.69 & 1055.5 & 20.78 & 262.28 & 4.37 & 9.1 & 231.7 & 24.51 & 19466 & $100 \%$ \\
\hline Total [\%] & $82.61 \%$ & $9.13 \%$ & $5.42 \%$ & $0.11 \%$ & $1.35 \%$ & $0.02 \%$ & $0.05 \%$ & $1.19 \%$ & $0.13 \%$ & $100 \%$ \\
\hline $\begin{array}{c}\% C h a n g e \\
\text { from 1859 }\end{array}$ & $25.83 \%$ & $-53.65 \%$ & $-49.38 \%$ & $-94.82 \%$ & $-3.48 \%$ & $-86.02 \%$ & $-17.20 \%$ & $462.38 \%$ & $139.12 \%$ & \\
\hline $\begin{array}{c}\% C h a n g e \\
\text { from 1973 }\end{array}$ & $9.90 \%$ & $-37.37 \%$ & $-30.26 \%$ & $-54.79 \%$ & $2.35 \%$ & $-60.27 \%$ & $-24.67 \%$ & $64.33 \%$ & $39.82 \%$ \\
\hline
\end{tabular}


Table 3. Comparative analysis of land use changes for five different elevation zones of the Ledro valley between the years 1859, 1973 and 2011 using the $\chi^{2}$ test and codes of the respective proportions of each date obtained by the means plot with $99 \%$ confidence limits

\begin{tabular}{|c|c|c|c|c|c|c|c|c|c|c|c|c|c|c|c|}
\hline \multirow{3}{*}{$\begin{array}{c}\begin{array}{c}\text { Altitude } \\
\text { [m a.s.l.] }\end{array} \\
2000-2300\end{array}$} & \multicolumn{5}{|c|}{ Forest } & \multicolumn{5}{|c|}{ Pastures } & \multicolumn{5}{|c|}{ Permanent meadow } \\
\hline & \multirow{2}{*}{$\begin{array}{c}\begin{array}{c}x^{2} \\
\text { (dff=2) }\end{array} \\
6.27\end{array}$} & \multirow{2}{*}{$\begin{array}{c}\text { P-value } \\
0.0435\end{array}$} & \multicolumn{3}{|c|}{185919732011} & \multirow{2}{*}{$\begin{array}{c}\begin{array}{c}\boldsymbol{x}^{2} \\
(\mathbf{d f}=2)\end{array} \\
6.34\end{array}$} & \multirow{2}{*}{$\begin{array}{c}\text { P-value } \\
0.042\end{array}$} & \multicolumn{3}{|c|}{185919732011} & \multirow{2}{*}{$\begin{array}{c}\begin{array}{c}x^{2} \\
(\mathbf{d f}=2)\end{array} \\
-\end{array}$} & \multirow{2}{*}{$\begin{array}{c}\text { P-value } \\
-\end{array}$} & \multirow{2}{*}{$\begin{array}{r}1859 \\
-\end{array}$} & \multirow{2}{*}{$\begin{array}{c}1973 \\
-\end{array}$} & \multirow{2}{*}{$\frac{2011}{-}$} \\
\hline & & & $b$ & $b$ & $b$ & & & $b$ & $b$ & $b$ & & & & & \\
\hline $1600-2000$ & 524.3 & $<0.001$ & c & c & $a$ & 425.3 & $<0.001$ & $a$ & a & c & 32.9 & $<0.001$ & $b$ & $a$ & c \\
\hline $1000-1600$ & 1209.2 & $<0.001$ & c & $a$ & $a$ & 723.1 & $<0.001$ & $a$ & c & c & 407.9 & $<0.001$ & a & c & c \\
\hline $600-1000$ & 241.78 & $<0.001$ & c & $a$ & $a$ & 264.8 & $<0.001$ & $a$ & c & c & 77.9 & $<0.001$ & $a$ & $b$ & c \\
\hline \multirow[t]{2}{*}{$65-600$} & 281.8 & $<0.001$ & c & $a$ & $a$ & 280.3 & $<0.001$ & $a$ & c & c & 15.98 & $<0.001$ & $a$ & $b$ & c \\
\hline & \multicolumn{5}{|c|}{ Arable land } & \multicolumn{5}{|c|}{ Inland waters } & \multicolumn{5}{|c|}{ Banks } \\
\hline $\begin{array}{l}\text { Altitude } \\
\text { [m a.s.I.] }\end{array}$ & $\begin{array}{c}\chi^{2} \\
(d f=2)\end{array}$ & P-value & 185 & 1973 & 2011 & $\begin{array}{c}x^{2} \\
(d f=2)\end{array}$ & P-value & 1859 & 1973 & 32011 & $\begin{array}{c}x^{2} \\
(d f=2)\end{array}$ & P-value & 1859 & 1973 & 32011 \\
\hline $2000-2300$ & - & - & - & - & - & - & - & - & - & - & - & - & - & - & - \\
\hline $1600-2000$ & - & - & - & - & - & - & - & - & - & - & - & - & - & - & - \\
\hline $1000-1600$ & 3.83 & 0.148 & $b$ & $b$ & $b$ & 1.37 & 0.504 & $b$ & $b$ & $b$ & - & - & - & - & - \\
\hline $600-1000$ & 546.9 & $<0.001$ & $a$ & c & c & 0.55 & 0.78 & $b$ & $b$ & $b$ & 14.1 & $<0.001$ & $a$ & $b$ & c \\
\hline \multirow[t]{2}{*}{$65-600$} & 49.6 & $<0.001$ & $a$ & c & c & 1.2 & 0.55 & $b$ & $b$ & $b$ & 13.2 & 0.002 & $a$ & $b$ & c \\
\hline & \multicolumn{5}{|c|}{ Inland wetlands } & \multicolumn{5}{|c|}{ Discontinuous urban fabric } & \multicolumn{5}{|c|}{ Buildings } \\
\hline $\begin{array}{l}\text { Altitude } \\
\text { [m a.s.I.] }\end{array}$ & $\begin{array}{c}\chi^{2} \\
(d f=2)\end{array}$ & P-value & 185 & 1973 & 2011 & $\begin{array}{c}\chi^{2} \\
(d f=2))\end{array}$ & P-value & 1859 & 1973 & 32011 & $\begin{array}{c}x^{2} \\
(d f=2)\end{array}$ & P-value & 1859 & 1973 & 32011 \\
\hline $2000-2300$ & - & - & - & - & - & - & - & - & - & - & - & - & - & - & - \\
\hline $1600-2000$ & - & - & - & - & - & - & - & - & - & - & 0.76 & 0.69 & $b$ & $b$ & $b$ \\
\hline $1000-1600$ & - & - & - & - & - & - & - & - & - & - & 1.47 & 0.48 & $b$ & $b$ & $b$ \\
\hline $600-1000$ & 0.42 & 0.81 & $b$ & $b$ & $b$ & 129.4 & $<0.001$ & c & $b$ & $a$ & 4.12 & 0.13 & $b$ & $b$ & $b$ \\
\hline $65-600$ & - & - & - & - & - & 6.4 & 0.041 & $b$ & $b$ & $b$ & 0.29 & 0.87 & $b$ & $b$ & $b$ \\
\hline
\end{tabular}

$+a$ : is for values above, $b$ : is for values inside and c: is for values below the $99 \%$ confidence limits in the ANOM plot of the proportion values of 1859, 1973, 2011 for a land use in the same elevation zone.

\subsection{Ecosystem services evaluation}

The results obtained from landscape analysis (Table 2 ) were combined with the updated values of services (Table 1) in order to assess the economical contribution of Ledro valley ESs during the 152-years period. Table 4 shows the total sum in millions $€$ /year (M€/yr) of the provided ESs for each ecosystem type during 1859, 1973 and 2011 while Table 5 shows the total sum in M€/year of a specific ES from all the existing ecosystem types during the respective years.

According to Table 4, it is observed that the overall value of ESs has been decreased about $5.39 \mathrm{M€} / \mathrm{yr}$ from $73.25 \mathrm{M€} / \mathrm{yr}$ in 1859 to $67.86 \mathrm{M€} / \mathrm{yr}$ in 2011 (total reduction -7.4\% during the 152-years period). This reduction is attributed to the expansion of forest mainly at the expense of grasslands but also of croplands, which both have greater contribution in the expensive Provisional services in comparison to forests (Table 1).

Considering the ES groups, it was observed that Provisional and Supporting services were reduced, while Regulation and Cultural services were increased (Table 5), with the intensity of their changes following the ranking scheme: Provisional $(-27.8 \%)>$ Cultural $(+17.6 \%)>$ Supporting $(-6.3 \%)>$ Regulation services (+3.5\%). 
Even though Provisional services showed the greater reduction/change among the rest ES groups, it was observed that this change was regulated by the respective reduction of "Food Production" and "Genetic Resources" since "Raw Materials" and "Water Supply" contribution was increased. In the case of Regulation services group, it was observed that "Climate Regulation", "Biological Control" and "Nutrient Cycling" were increased while all the rest ESs were reduced, leading to a final positive change for this group of services. In the case of Supporting services, all the ESs were negatively affected and especially the "Habitat refugia". The case of Cultural services group is of special interest since the "Recreation" contribution significantly increased, mitigating the reduction of the overall ESs. Finally, analysis was performed on the annual rates of change $r_{c}$ for each ES but also for each ES group between the periods of 1859-1973 and 1973-2011 (Fig. 2). The results showed that the $r_{c}$ values were higher during the period 1973-2011 for all ES groups (Fig.2a) but also for each individual ES except "Water Regulation" and "Soil Formation" (Fig.2b). These two ESs showed higher $r_{c}$ values during 1859-1973 due to the expansion of forest at the expense of pastures, which was found to be higher before 1973 in the elevation zones between 65-1600 m (Table 3).

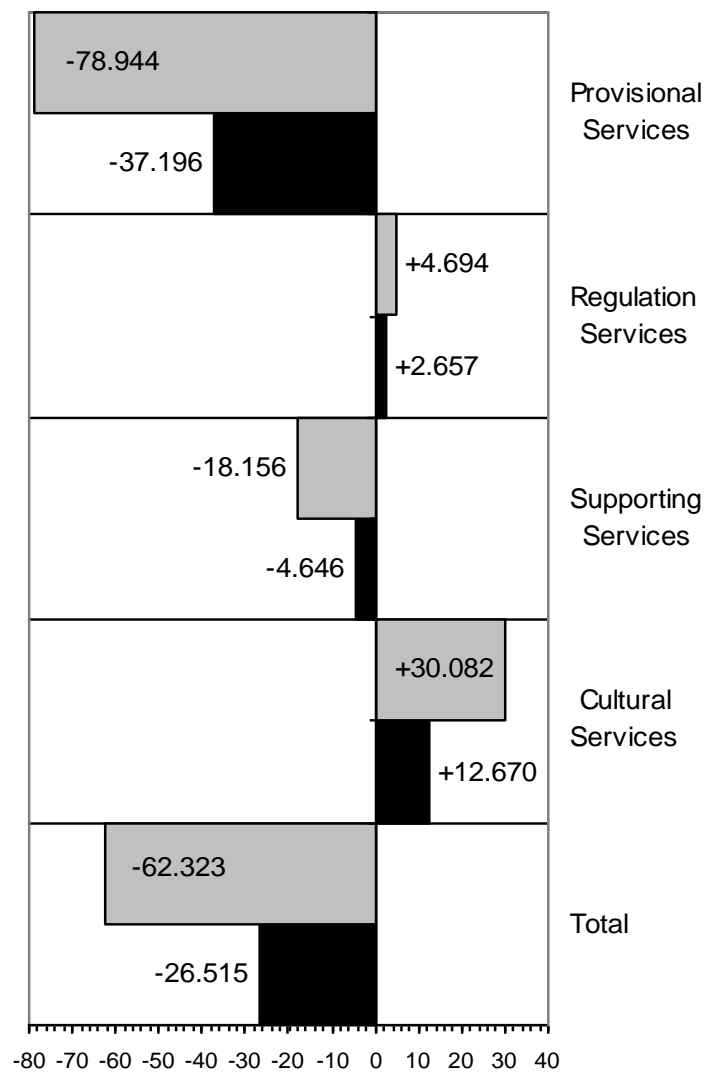

a) Annual rate of change $r_{c}(K \in / y r)$

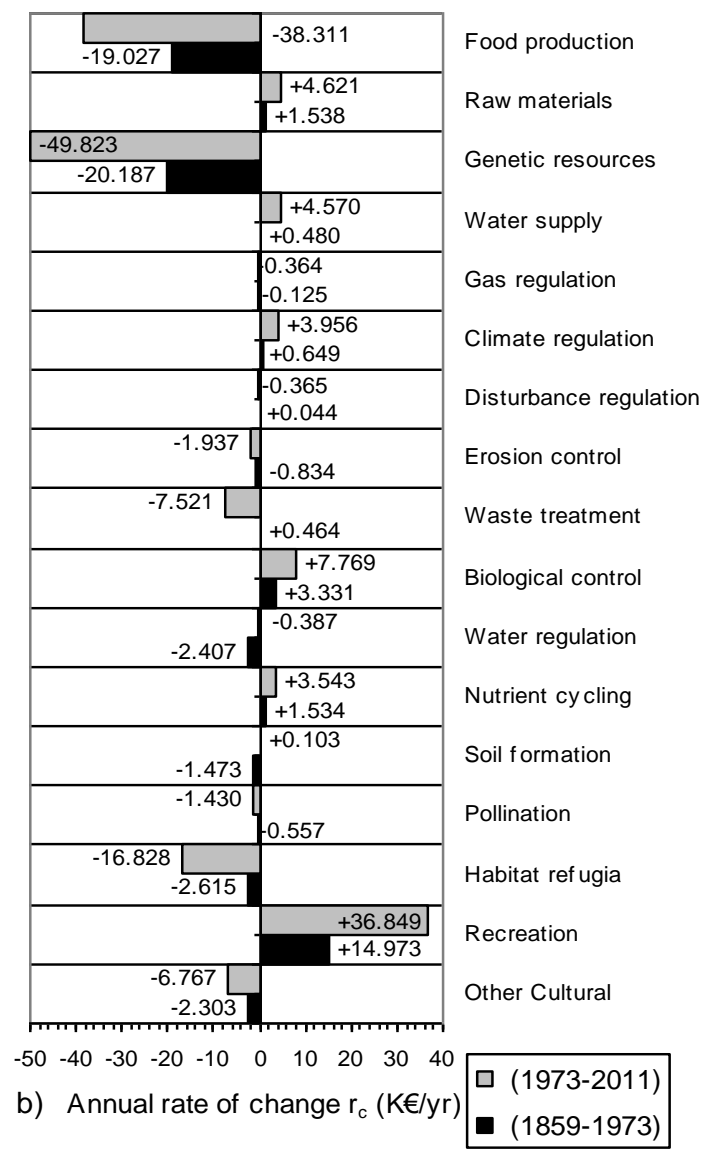

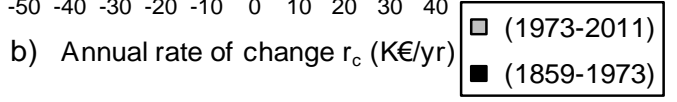

Figure 2. Annual rate of change $r_{c}$ a) for each ES group and $b$ ) for each individual ES during the periods 1859-1973 and 1973-2011

\section{Discussion}

The absence of significant changes in the landscape above $2000 \mathrm{~m}$ and the significant changes below this elevation during the 152-years period suggest that the observed landscape evolution in Ledro valley is mainly associated to human activities rather than climate changes (Vittoz et al., 2009). The general trends verify the findings of other authors from similar study areas in Alpine and Mediterranean environments 
(Gehrig-Fasel et al., 2007; Gellrich et al., 2007; Cramer et al., 2008; Tasser et al., 2005,2007; Geri et al., 2010; Schirpke et al., 2013), which have experienced a conversion from a rural and subsistence economy, to an economy based on handcrafting and tourism. Regarding the urbanization phenomenon, the number of inhabitants in Ledro Valley increased from 4708 inhabitants in 1834 to 5523 in 2014, even though other mountainous areas face an increasing depopulation process (Lehringer et al., 2003), which enhances the phenomenon of land abandonment and consequently forest expansion.

Table 4. The total sum in M€/yr of the provided ecosystems services for each ecosystem type during 1857, 1973 and 2011 and gain/loss (G/L) in M€/yr between the respective dates

\begin{tabular}{ccccccc}
\hline \multirow{2}{*}{ Date } & \multicolumn{7}{c}{ Ecosystem type } \\
\cline { 2 - 7 } & Forest & Grasslandst & Inl. wetlands & Inl. Waters $\neq$ & Croplands & Total \\
\hline 1859 & 40.634 & 24.962 & 1.559 & 3.837 & 2.258 & 73.250 \\
\hline 1973 & 46.523 & 18.348 & 1.714 & 3.384 & 0.259 & 70.227 \\
\hline 2011 & 51.130 & 11.945 & 1.291 & 3.376 & 0.117 & 67.859 \\
\hline G/L (1859-1973) & 5.889 & -6.614 & 0.155 & -0.452 & -1.999 & -3.023 \\
\hline G/L (1973-2011) & 4.608 & -6.403 & -0.423 & -0.008 & -0.142 & -2.368 \\
\hline G/L (1859-2011) & 10.496 & -13.018 & -0.268 & -0.460 & -2.141 & -5.391 \\
\hline
\end{tabular}

FIncludes "Pastures" and "Permanent Meadows", ¥Includes "Inland waters" and "Sandy river banks"

Table 5. The total sum in M€/year of a specific ecosystem service from all the existing ecosystem types during 1857, 1973 and 2011 and gain/loss (G/L) in M€/yr between the respective dates

\begin{tabular}{|c|c|c|c|c|c|c|c|}
\hline \multirow{2}{*}{\multicolumn{2}{|c|}{ Ecosystem Services in $M € / y r$}} & \multicolumn{3}{|c|}{ Date } & \multicolumn{3}{|c|}{ G/L } \\
\hline & & 1859 & 1973 & 2011 & $(1859-1973)$ & $(1973-2011)$ & $(1859-2011)$ \\
\hline \multirow{5}{*}{ 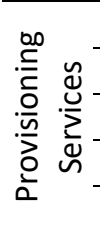 } & Food production & 11.994 & 9.825 & 8.370 & -2.169 & -1.456 & -3.625 \\
\hline & Raw materials & 2.758 & 2.933 & 3.109 & 0.175 & 0.176 & 0.351 \\
\hline & Genetic resources & 7.700 & 5.398 & 3.505 & -2.301 & -1.893 & -4.195 \\
\hline & Water supply & 3.557 & 3.612 & 3.785 & 0.055 & 0.174 & 0.228 \\
\hline & Total Prov. Services & 26.009 & 21.768 & 18.769 & -4.240 & -3.000 & -7.240 \\
\hline \multirow{9}{*}{ 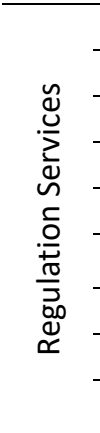 } & Gas regulation & 0.054 & 0.040 & 0.026 & -0.014 & -0.014 & -0.028 \\
\hline & Climate regulation & 2.374 & 2.448 & 2.599 & 0.074 & 0.150 & 0.224 \\
\hline & Disturbance regulation & 0.051 & 0.056 & 0.042 & 0.005 & -0.014 & -0.009 \\
\hline & Erosion control & 0.411 & 0.316 & 0.242 & -0.095 & -0.074 & -0.169 \\
\hline & Waste treatment & 3.682 & 3.735 & 3.449 & 0.053 & -0.286 & -0.233 \\
\hline & Biological control & 3.242 & 3.621 & 3.917 & 0.380 & 0.295 & 0.675 \\
\hline & Water regulation & 2.342 & 2.067 & 2.053 & -0.274 & -0.015 & -0.289 \\
\hline & Nutrient cycling & 1.209 & 1.384 & 1.519 & 0.175 & 0.135 & 0.310 \\
\hline & Total Regul. Services & 13.365 & 13.668 & 13.846 & 0.303 & 0.178 & 0.481 \\
\hline \multirow{4}{*}{ 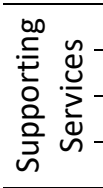 } & Soil formation & 0.409 & 0.241 & 0.245 & -0.168 & 0.004 & -0.164 \\
\hline & Pollination & 0.219 & 0.155 & 0.101 & -0.063 & -0.054 & -0.118 \\
\hline & Habitat refugia & 18.560 & 18.262 & 17.623 & -0.298 & -0.639 & -0.938 \\
\hline & Total Support. Services & 19.188 & 18.658 & 17.968 & -0.530 & -0.690 & -1.220 \\
\hline \multirow{3}{*}{ 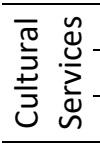 } & Recreation & 13.668 & 15.375 & 16.775 & 1.707 & 1.400 & 3.107 \\
\hline & Other Cultural & 1.021 & 0.758 & 0.501 & -0.263 & -0.257 & -0.520 \\
\hline & Total Cult. Services & 14.689 & 16.133 & 17.276 & 1.444 & 1.143 & 2.588 \\
\hline \multicolumn{2}{|c|}{ Total of Ecosystem Services } & 73.250 & 70.227 & 67.859 & -3.023 & -2.368 & -5.391 \\
\hline
\end{tabular}

As concerns the changes in the provided ESs, it was found that the observed landscape evolution decreased their overall economic contribution through a non-counterbalanced decrease of some ESs versus others, which showed an increase of lower intensity. From an economical point of view, the renaturalization of the environment according to the given values of ESs (Table 1) reduces the economic profit. This trend is strongly associated to the management strategies of the local economies and can be easily reversed if decision-makers and local stakeholders make serious efforts to maximize the final profit from specific ES favored by the forest expansion, which have direct economical contribution to the society 
(e.g. recreation activities through tourism). Such efforts could be the key to achieve both sustainable economical growth and environmental management (Marini et al., 2011).

From an ecological point of view, it was also observed that the re-naturalization of the environment had negative effects on some services, which play significant role on the ecological and environmental quality of the environment (e.g. Habitat refugia availability, and genetic resources etc). These effects have been considered as a consequence of the gradual abandonment of traditional practices, showing the need to incorporate intervention strategies in landscape planning for the maintenance and management of the typical rural landscape and grasslands.

\section{Conclusions}

This study revealed the changes that occurred in the alpine landscape of Ledro valley for a 152-years period (1859-2011) and their effects on the provided ESs of the territory. The analysis of landscape evolution highlighted the forest expansion, and partially the urban expansion, at the expense of grasslands and croplands due to a transition from a rural economy to a touristic and handcrafting economy. The observed land-use changes led to an overall reduction of the ESs economical contribution while the detailed analysis of each ES changes allowed to identify advantages and disadvantages caused by the renaturalization process of forest expansion. The results suggest that the maximization of ESs under the pressure of such land-use changes can be achieved by a respective maximization of the profits from services related to recreation activities (tourism), which have an immediate economical impact on local economies, together with the maintenance and sustainable management of the typical rural landscape and grasslands in order not to loose some of their benefits to the ecological quality of the landscape.

\section{References}

AA.VV. (2012), Trentino, landscapes, nature, places \{Naturalmente Trentino. I paesaggi, la natura, I luoghi\} Commissione Tutela Ambiente Montano, Trento, 26-45. (in Italian)

Bennett E.M., Peterson G.D. and Gordon L.J. (2009), Understanding relationships among multiple ecosystem services, Ecology Letters, 12, 1394-1404.

Chauchard S., Carcaillet C. and Guibal F. (2007), Patterns of land-use abandonment control tree-recruitment and forest dynamics in Mediterranean mountains, Ecosystems, 10, 936-948.

Cigalotti E. (1973) Through the Ledro Valley \{Attraverso la Val di Ledro\}, Trento: 17-20. (in Italian)

Cocca G., Sturaro E., Gallo L. and Ramanzin M. (2012). Is the abandonment of traditional livestock farming systems the main driver of mountain landscape change in Alpine areas?, Land Use Policy, 29, 878-886.

Costanza R., Arge R., De Groot R., Farber S., Grasso M., Hannon B., Limburg K., Naeem S., Oneill R.V., Paruelo J., Raskin R.G., Sutton P. and Van Den Belt M. (1997), The value of the world's ecosystem services and natural capital, Nature, 387, 253-260.

Costanza R., de Groot R., Sutton P., van der Ploeg S., Anderson S.J., Kubiszewski I., Farber S. and Turner R.K. (2014), Changes in the global value of ecosystem services, Global Environmental Change, 26, 152-158.

Cramer V.A., Hobbs R.J. and Standish R.J. (2008), What's new about old fields? Land abandonment and ecosystem assembly, Trends in Ecology and Evolution, 23, 104-112.

De Groot R., Brander L., Van Der Ploeg S., Costanza R., Bernard F., Braat L., Christie M., Crossman N., Ghermandi A., Hein L., Hussain S., Kumar P., Mcvittie A., Portela R., Rodriguez L.C., Ten Brink P. and Van Beukering P. (2012), Global estimates of the value of ecosystems and their services in monetary units, Ecosystem Services, 1, 50-61.

Ferrari M. and Geneletti D. (2014), Mapping and assessing multiple ecosystem services in an Alpine region: a study in Trentino, Italy, Annali di Botanica, 4, 65-71.

Fontana V., Radtke A., Fedrigotti V.B., Tappeiner U., Tasser E., Zerbe S. and Buchholz T. (2013), Comparing land-use alternatives: Using the ecosystem services concept to define a multi-criteria decision analysis, Ecological Economics, 93, 128-136. 
Gehrig-Fasel J., Guisan A. and Zimmermann and N.E. (2007), Tree line shifts in the Swiss Alps: Climate change or land abandonment?, Journal of vegetation science, 18, 571-582.

Gellrich M., Baur P., Koch B. and Zimmermann N.E. (2007), Agricultural land abandonment and natural forest regrowth in the Swiss mountains: a spatially explicit economic analysis. Agriculture, Ecosystems and Environment, 118, 93-108.

Geri F., Amici V. and Rocchini D. (2010), Human activity impact on the heterogeneity of a Mediterranean landscape, Applied Geography, 30, 370-379.

Grêt-Regamey A., Walz A. and Bebi P. (2008), Valuing ecosystem services for sustainable landscape planning in Alpine regions, Mountain Research and Development, 28, 156-165.

Lehringer S., Höchtl F. and Konold W. (2003), Effects of land use changes and depopulation on landscape, social life and tourism-overview about the results of a case study from the Piedmont Alps in Italy, Centralblatt für das gesamte Forstwesen, 120, 1-18.

Marini L., Klimek S. and Battisti A. (2011), Mitigating the impacts of the decline of traditional farming on mountain landscapes and biodiversity: a case study in the European Alps, Environmental Science and Policy, 14, 258-267.

Nelson E., Mendoza G., Regetz J., Polasky S., Tallis H., Cameron D.R., Chan K.M.A., Daily G.C., Goldstein J., Kareiva P.M., Lonsdorf E., Naidoo R., Ricketts T.H. and Shaw MR. (2009), Modeling multiple ecosystem services, biodiversity conservation, commodity production, and tradeoffs at landscape scales, Frontiers in Ecology and the Environment, 7, 4-11.

Prévosto B., Kuiters L., Bernhardt-Römermann M., Dölle M., Schmidt W., Hoffmann, M. and Brandl R. (2011), Impacts of land abandonment on vegetation: successional pathways in European habitats, Folia Geobotanica, 46, 303325.

Piccolroaz S., Toffolon T., Sighel M.C. and Bresciani M. (2013), On the impact of climate change on surface water temperature of Lake Garda, Geophysical Research Abstracts, 15, EGU2013-8406.

Power A.G. (2010) Ecosystem services and agriculture: tradeoffs and synergies, Philosophical transactions of the royal society B: biological sciences, 365, 2959-2971.

Rutherford G.N., Bebi P., Edwards P.J. and Zimmermann N.E. (2008), Assessing land-use statistics to model land cover change in a mountainous landscape in the European Alps, Ecological Modeling, 212, 460-471.

Schirpke U., Leitinger G., Tasser E., Schermer M., Steinbacher M. and Tappeiner U. (2013), Multiple ecosystem services of a changing Alpine landscape: Past, present and future, International Journal of Biodiversity Science, Ecosystems Services and Management, 9, 123-135.

Scolozzi R., Gretter A., Orsatti C. and Goio I. (2010), Toward an evaluation of ecosystem services within alpine tourism, a case study at Ledro Valley (TN). In XIX Congresso della Società Italiana di Ecologia" Dalle vette alpine alle profondità marine": 241-248. (in Italian)

Tasser E., Tappeiner U. and Cernusca A. (2005), Ecological effects of land-use changes in the European Alps. In Global Change and Mountain Regions (pp. 409-420). Springer Netherlands.

Tasser E., Walde J., Tappeiner U., Teutsch A. and Noggler W. (2007), Land-use changes and natural reforestation in the Eastern Central Alps, Agriculture, Ecosystems and Environment., 118, 115-129.

Vittoz P., Randin C., Dutoit A., Bonnet F. and Hegg O. (2009), Low impact of climate change on subalpine grasslands in the Swiss Northern Alps, Global Change Biology, 15, 209-220. 